821.163.4.09-312.6 Drndić M.

314.151.3-054.72(71): 821.163.4.09

https://doi.org/10.18485/asec_sacs.2021.9.ch10

\author{
Vladislava Gordić Petković* \\ University of Novi Sad, Serbia
}

\title{
THE CANADIAN CONDITION: MIGRATION \\ OF INTELLECTUALS AND ARTISTS \\ IN POST-YUGOSLAV FICTION
}

\begin{abstract}
Distancing herself from fixed national canons and identities, belatedly famous novelist Daša Drndić chose to occupy a political and artistic position of permanent exile. Therefore, her literary work will be examined in the context of the post-Yugoslav literary canon, which is still in the making. The paper will present Drndić's novels as part of a transnational, or supranational, corpus of literature and art that share thematic, stylistic, formal and ideological concerns, focusing on her Canadian experience. Her disappointing emigration period spent in Canada in the late 1990's (1995 to 1997) resulted in the semiautobiographical novel Maria Częstohowska Still Shedding Tears or Dying in Toronto (1997). Drndić's novel brings together diverse memories, notes and documents that testify to intellectual crisis, feelings of isolation and defeat as well as to a terrible humiliation lurking behind the apparent security and comfort offered to a displaced person. Daša Drndić narrates about her Canadian migrant experience as a series of losses: country, memory, language, art and identity. Displacement is too painful a condition to be simply shrugged off as a temporary crisis, but the author refuses to rescue herself by leaving the turbulent history of her lost homeland behind: she prefers to return to it with a renewed potential of both self-examination and suffering.
\end{abstract}

\section{Keywords}

*vladysg@yahoo.com 
Migration, Canada, narrative, exile.

\section{Art and Migration: A Short Introduction into the Serbian and post-Yugoslav Fiction Travelogue}

In order to announce the forthcoming book Migrations: Open Hearts, Open Borders, The Observer of May $4^{\text {th }} 2019$ publishes an article about the exhibition of three hundred postcards visualizing migrant stories. The illustrators, invited through social media and word of mouth, were supposed to contribute a bird postcard, as a metaphor for human migration, with a message attached. It could be whatever the illustrators liked: a poem, a quote, a personal greeting and had to carry a postage stamp from their country. Mohammad Rasht from northern Iran, who now lives in the UK, contributed a metaphorical illustration in order to explain his own migrant experience. He invented a "legendary" bird that will transport people safely to the lands of their dreams. Since he has a disability in his left hand and makes his prints partly through using his leg, his illustration turned out to be a triumph over circumstance. The postcards on the exhibition were hung on vertical wires, since the organizers' intention was to "replicate the precarious nature of flight". If you touched a card, the others would swivel and move, the entire structure would tremble, which actually produced a silent communications network.

When we cast a look at the novels recently published in Serbia and several other regions of former Yugoslavia, we get a similar impression: reading any of them invites the entire body of literature to react - that is, to move, to tremble and to produce a silent, yet memorable response, and a lasting sensation. The migration, displacement and the inner and outer changes caused by leaving one's homeland and accompanying the process or reintegration are dutifully reflected in art and culture and will always be. There is more than one novel within the post-Yugoslav literary canon (which is, to tell the truth, still in the making) that opposes strict definitions in terms of topic, space, history and identity, or belonging. These few novels might be written with artistic intentions which vary to a great extent and within a scope of opposing thematic or stylistic tenets, but they have at least one element in common: they all reach beyond the limits of national history and national identity even as they contrapuntally evoke the former state and its values in the readers' imagination. These novels integrate borderline territories and temporary residences into a rich and provocative multilayered structure.

Being provocative and compelling, original and controversial at the same time, novels by such diverse writers as Dubravka Ugrešić, David Albahari, Daša Drndić, Dragan Velikić, Ivančica Đerić, Slavenka Drakulić, Jelena Lengold and several other Serbian, Croatian and Bosnian authors decidedly develop plots 
and ideas which defy an easy classification and deserve a further elaboration. In these books, national memory is first evoked and then contested, disrupted and reinterpreted. By using the term post-Yugoslav, we choose to form an image or a memory (either haunting or idyllic) which invites a return to the Yugoslav past and opts for the invention of a transnational, or supranational, corpus of literature and art sharing thematic, stylistic, formal and ideological concerns. Furthermore, this post-Yugoslav literary canon need not insist on continuity with art and literature that existed before the collapse of the common Yugoslav state.

Abrupt historical changes call for gradual change of interpretational strategies and priorities. According to Azade Seyhan, "our critical terms for literary study are not adequate for an exploration of these transfigurations. The emergent literatures of deterritorialized peoples and literary studies beyond the confines of national literature paradigms have as yet had no name or configuration." (Seyhan 2001: 9). This is the reason why a substantially altered strategic and comparative approach is needed when we discuss the post-Yugoslav writing.

The novels which we can term post-Yugoslav cannot be simply placed into established traditions and conventional frameworks. Manipulating documents, facts and fantasy has become the strongest card lavishly used by contemporary post-Yugoslav fiction, which aims not to gratify the refined palates of its readership, but to obtain a penetrating, bitter insight into turbulent histories and disturbing destinies, hoping to turn them into inspiring and mysterious reinventions of reality. Literature is meant to incite an emotional response both from the experience of the creator and the consumer: it can surprise the reader and incorporate widely contradictory, unwieldy and confusing emotions, but it also rushes into provoking feelings which are not easily explained. Both surprise and provocation can be useful mechanisms to those writers who navigate their movements in space and memories in time, in a desperate effort to reestablish the lost homeland and the new protocols of life and death found in exile.

The reason to classify Daša Drndić, David Albahari, Dragan Velikić or Ivančica Đerić, along with others previously mentioned, as post-Yugoslav authors could be naturally as well as logically supported by the fact that all of them spent their formative years in the former Yugoslavia, in a system that shaped their interests and beliefs in a foreseeable, expected way: they created and cherished numerous ties to the former state which they still consider their homeland, as opposed to the younger generation of authors from the Balkans whose reception of the Yugoslav past mostly relies upon their parents' testimonies and memories. The novels such as Catch the Rabbit by thirtysomething Lana Bastašić (published in 2018) cut very deep into the feeling of alienation imposed by either the traumatic overdose of history, or an individual anxiety caused by transfigured realities. Bastašić represents diverging memories and concepts connected with her characters' homeland which was willfully abandoned as limiting and 
retrograde, but constantly longed for and therefore narrativized. The Balkans road-movie narrative of Catch the Rabbit finds its own way to express the pain, anger, memory and longing through carefully developed imagery of travel and friendship.

The writers who have experienced an exiled life, and written migration into their narrative, have established a very convincing way of dealing with psychological and cultural aspects of estrangement. Even if they do not openly protest against the fragmentation of their identity, they tend to contemplate the past and the present in the way that helps their fruitful reintegration.

During his self-imposed expatriate life in Canada, David Albahari has reinvented his fiction, focusing on a continual quest for stability, for valid discourse, self-explanation and self-identification on the background of contradictory impulses of rememory and self-oblivion. There is nevertheless an inexplicable melancholy and silent retrospection within his characters' repetitive acts of memory and reconsideration. An irresistible wish to plunge into history and contemplate the horrible irregularities and frightening randomness of the ruling ideologies, either leftist or nationalistic ones, has taken Albahari to the thorough reconsideration of the family as a permanent element of his fiction, and to question its stability. Once in the remote past, the family life and familial background used to be the magic spot where the stories of individual initiation intersect: this period of Albahari's writing ended with his emigration to Canada. Later on, on the far-off territory, the family circle gradually turned into a treasure-box of hidden historical testimonies. With the Canadian backdrop to the identity dilemmas of his characters and narrators, Albahari seemed to become haunted by the feelings of estrangement and filial bereavement more than ever. These sentiments were obviously imposed by either the sudden rush of turbulent local history, which is felt to be more intense after moving away from the homeland, or a collective neurosis caused by a conflict of belonging.

It is interesting to note in retrospect that Daša Drndić and David Albahari apply topically and methodologically different approaches to the identical, burning issues of European twentieth century history: while Albahari's text is continuous, flowing totally neglectful of chapters or paragraphs and thus bearing close resemblance to Kafka's, Daša Drndić boldly inserts visual elements that disrupt the text: photos, maps and long lists of facts and figures. All of these seemingly disjointed elements are introduced in order to strengthen the narrative with the addition of history and the personal experience alike. When tackling the history of the twentieth century in the Balkans, Albahari chooses to write only about the extermination of Jews in Belgrade, whereas Drndić discusses the atrocities committed throughout Europe, covering a wide range of territory, from Italy, Croatia, Germany and Austria to Sweden and Norway. Characters in Albahari's Canadian novels and Drndić's Sonnenschein are similar in being high-school 
teachers, but despite their profession they remain incapable of communicating the facts and impressions of the Holocaust to their students. The characters' inability to spread the word of the common experience are connected to their readiness to move and migrate, since the officially recognized historical truths willfully obliterate the strong personal experience of political turmoil, leaving them helpless and vanquished.

In his short stories written since 1997, David Albahari has demonstrated a passion to portray expatriate intellectuals and Bohemians and to question one's character, thoughts and habits against the background of the immigrant experience, desperately looking for balance, hoping for both reinvention and redefinition of the newly found existence. Albahari's fiction set in the contemporary Canada mirrors the challenging ethnic and cultural diversities that lie in wait when the characters try to rebuild their lives far from the painful and incomprehensible history of their homeland. For instance, in the story "Learning Cyrillic", a man teaching Cyrillic to Serbian children in a North American town becomes friend of a Blackfoot Indian called Thunder Cloud, whose folk tales intermingle with the narrator's memories and the legacy of Serbian Ortodox Church. Whenever the story takes place in Canada, the plot thickens with deepening the gap between secretly harboured wishes and hopes on the one hand and the pervading sense of the ultimate defeat on the other. David Albahari introduces Canada as the new setting to his characters' existential and spiritual dilemmas, treating it as a potentially idyllic place which imminently triggers new doubts and fears. His characters have fled from conflicts and traumas, but cannot be rescued if they do not affront their destiny. Despite the artistry of the simple and concise idiom, Albahari's stories and novels seem to end in an absurd interruption or disruptive silence, never complying with the logic of the narrative structure and composition. This kind of ending tends to be a mutual strategy of coping with fear and pain, since most of post-Yugoslav writers desperately look for the way to deal with the trauma of ethnic divisions and the cruel fragmentation of the former homeland, which used to be both an exciting cultural space and a promising spot of cultural diversity.

\section{Artivism in Serbian Fiction}

In her critically acclaimed novel The Gorgons (Gorgone, 2017) Serbian writer and playwright Mira Otašević discusses the history of Europe ranging from the time of Nazism and Holocaust up to the present European migrant crisis, using a choice of carefully selected plots and narrative strategies, with the help of avant-garde techniques of collage, juxtaposition and montage. Otašević engages in conflating biographical records of $20^{\text {th }}$ century artists with some partly fictionalized testimonies of the authentic figures who influenced and inspired their 
work. The greatest part of her sixth short novel mixes fictionalized biographies of artists, sportsmen and historical personages in the wake of the Second World War, amid their respective dramas of experiencing ostracism, social rejection and political molestation.

Unlike most of her fellow writers, Mira Otašević chooses to engage in activity called artivism. This term gains importance in the aftermath of the international migrant situation: a compound word made of art and activism, the newly coined compound artivism stands for an old strategy: it implies using artistic talents to fight against injustice and oppression of the society. An artivist is committed to justice, equality, peace, freedom and human rights the same as any activist, but the difference between being an artist and acting as an artivist lies in the fact that the latter uses his or her imagination, body, pen or brush to express the political attitude in an empowered way and to start a long and persistent struggle for change. Art has always been a powerful tool for activists, as it can grapple with the world's anomalies and bring about change by challenging oppression. Artivism here operates to focus on people who are marginalized, ignored or denied power and influence. Through collaboration with the subjects of social exclusion, the artists transform the way the observers perceive the world, and also the way the subjects see themselves.

Mira Otašević blends scarce facts and fiction while she reconstructs and reinvents the biography of one in the row of her heroes and heroines, a deported Romani girl Settela Steinbach. Settela was on the train which transported Roma and Jews to Auschwitz-Birkenau, peeping through an opening and showing just a piece of torn sheet covering her shaven head. The image of the anonymous young girl, staring out of the wagon in a strangely calm manner, became an icon of the Holocaust. Until 1994 she was only known as "the girl with the headdress", assumed to be Jewish, and nothing was known about her life and death. Otašević makes an attempt to reconstruct what could have been an ordinary childhood filled with intense emotions, passions and unfulfilled wishes, trying to be a sympathetic witness in a swirling fluid mess of memory and time.

Merging historical facts and fictitious characters in much the same way like Otašević does, Dejan Atanacković follows in the footsteps of its unknown predecessor, Judita Šalgo, whose fragmented, posthumously published novel A Voyage to Birobijan reads as a gospel of the entire destitute womanhood, addressing the alternative history which belongs to the female Christ figure named Messiana and the army of her followers who firmly believe in the existence of an Utopian refuge for all the underprivileged and deprived. The leading thread of Atanacković's novel Lusitania is similarly alternative, as it participates in a discussion (that has been going on for centuries) about the ambivalent and multifocal connections of reason and madness through a showcase of human stupidity and its numerous incarnations of the modern era. The inclination 
toward both the political and the fantastic can also be observed in the fictional opus of unkindly forgotten Sreten Ugričić, which is positioned in between political allegory and a modern fairy tale filled with the element of the uncanny. As elsewhere, the intrusion of fantastic elements begins with the character's perception of reality as monstrous and perverted. Thus in his to this day latest novel, To the Unknown Hero (Neznanom junaku, 2010), Ugričić skillfully combines the burning issue of Serbian province of Kosovo with dystopia and fable, turning the Serbia of the year 2014 into a bleak country packed with terror and ignorance, corruption and unrest, and the only free media in such a dismal place is confined to - telepathy. The love story in such a dystopic world imminently ends in pain, tears and tragedy, but even the much used convention of star-crossed lovers leads to an unexpected twist: the lovers die of gas poisoning after spending only one night together, their death happening before they have managed to become the principal narrative concern of the plot. Ugričić boldly uses history and politics as deconstructed metaphors in order to show that they suffocate love and life in general: an inscription on the wall, saying "Serbia; it'll kill ya", turns from a banal reality bite into a fully developed concept of danger and death, which overshadows the world of the novel. The all-pervading existential fear does not stem from political threats only: Ugričić surpasses the paradigms of postcommunism, entering the realm of the postapocalyptic world.

Inclined to investigate personal histories hidden behind the walls of European cities from the Mediterranean to the Central Europe, Dragan Velikić is deeply concerned with exile as the condition of the modern subject, particularly the postcommunist one, who lost the illusion of sharing the dream of capitalism even before daring to embrace it. Thus his character Rudi Stupar from the critically acclaimed novel The Russian Window (Ruski prozor, 2007) travels from his hometown Subotica further to the north in order to invent a new life unburdened with ethnic animosities and war conflicts. Similar to Albahari's characters, Rudi wants to escape the historical overdose which is inexcapable in his homeland Serbia, and he desires to break the unbearable routine of living in between wars or intermittent political crises. First Rudi successfully resettles in Budapest, until the city turns into a "Serbian Casablanca" with the flow of Serbian expatriates who have escaped the NATO air strikes in the spring of 1999. Velikić is at his best when he casts his elaborate sketches of the cities ranging from Pola to Hamburg, which get to be much more than a mere backdrop to the characters' identity crises and migration impulse. His characters belong to a paradigm of self-confident yet dissatisfied lonely men who try to come to terms with their historical, cultural and intimate heritage, looking for their idols and friends among the figures of prominent artists who set the example of successful reconciliation of love, ambition and faith. The sacredness of art replaces the nightmare of belonging to the dreary world the heroes hope to change. 
Rudi Stupar will reemerge in the later novel by Dragan Velikić, Bonavia (2012), but just as a sad sidekick who reaps success in Germany with one of his plays. He is just a man who accidentaly shows up on the funeral of Raša Borozan's ex-girlfriend. Bonavia is at its best when it represents the paradox of the intersected paths and discontinued destinies: although the paths of the respective migrating characters are crossing and intersecting all the time, the characters do not meet and remain oblivious of one another. They miss each other, they misunderstand each other, and although they refer to the mutual memories from the past, but there is no connection, no resonance, no echo. The five central characters (Marko, Marija, Miljan, Kristina and Raša) appear to be mere variations to a single paradigm of traits: on a higher, more general plane they embody the individual initiative to change the course of one's destiny, which seems to be futile in a conflicting and conflicted society as Serbian is. Strange encounters of various characters seem to defy both history and geography: in Vienna, Kristina witnesses Marko's father's heart attack, whereas Marija observes the ambulance taking Kristina to the hospital after she suffered stroke. Marko, Kristina and Marija spend some time in the hotel Urania, Marko and Kristina even run into each other, but Kristina mistakes him for a porter. In the section narrated by Marko's father Miljan we learn that he had The-Night-Porter type of affair with Danica, who is Kristina's grandmother and at the same time her imaginary friend and a role model. Danica is mostly a construct, an elusive force of solitude and change, necessary to the plot so that it can reinvent the bleak reality of the characters confined within their fixed identities and unsecure routes. Velikić's main character Marko Kapetanović is a dangling man without proper vocation, always missing a clear objective in life. His roles as a father, son and lover are fake and deficient, revealing that until the very end of the novel he keeps acting as emotionally uninvolved to the point of numbness. While writing a novel that should be the climax of his success and the strategy to rise above less exciting tasks such as writing travel books, he keeps missing the essential points of art and living. Fully ilusional but not incapable of self-criticism, Marko considers his destiny in a row of conditionals, as a cluster of whats and ifs: what if his mother did not die at childbirth, what if his father, an overachiever who chose to become a restorant owner, made altogether different decisions, and so on, and so forth.

Apart from migration, the basic motive of the novel Bonavia is the flight from reality in its various forms: fleeing from either unwanted or insufficiently loved lovers and wives, fleeing from both a country and a culture that no longer fulfill expectations (for instance, Kristina leaves for America after the assasination of Serbian Prime Minister Zoran Djindjic) and also the impossibility to change the course of one's destiny without the impact of political changes. 
A carefully constructed parallel to the disciplined and composed character of Marko is Raša Borozan, a self-sufficient poet living in splendid isolation, an immigrant wilfully hidden within his small world: this figure of an artist and arbiter elegantiarum, based upon the actual character of one of the best Serbian poets Raša Livada, displays an utter lack of ambition and motivation. Borozan is an expatriate in his own country who rejects to address duties and pleasures alike. Borozan refuses both work and travel as kinds of unnecessary involvement and incontrollable waste, claiming that neither diligence should be overpriced, nor leisure underestimated. He writes poetry only rarely, trying to live life to the fullest, choosing Zemun to be his continent, following thus in the footsteps of Cavafy and Pessoa, his role models and favourite poets.

\section{Daša Drndić: Migrations in and out of History}

Daša Drndić, was born on 10 August 1946 in Zagreb, and died on 5 June 2018 in Rijeka. Her life started in Zagreb, at the time when Croatia was part of the Socialist Federal Republic of Yugoslavia, but the greatest part of her professional life was spent in Belgrade. She was born into a middle-class family of intellectuals who successfully shaped her attitudes and beliefs. Daša Drndić's mother, Timea, was a psychiatrist, whereas her father, Ljubo, who had been a wartime partisan in Istria, became a diplomat, serving as ambassador to Sweden and Sudan. Daša Drndić studied English language and literature at the University of Belgrade. She obtained a master's degree in theatre and communications in the United States and studied for a PhD at the University of Rijeka, where she later in life worked as professor and taught English drama and creative writing. Drndić spent many years in the drama department of the Radio Belgrade as an editor, playwright and producer, having created a rich radiophonic legacy. Seeing the disastrous course of the events of the 1990s (the growth of nationalism and the outbreak of a fratricidal war which deeply affected her professional and private life), Daša Drndić decided to leave Serbia for Croatia, but before very long she changed her mind and left for Canada. After coming back from Toronto for good, she settled in Rijeka, and lived there for 25 years.

Distancing herself openly from fixed national canons and imposed identities, abhorring nationalism both in Serbia and Croatia as well as any kind of hatred and discrimination, Daša Drndić chose to occupy a political and poetic position of permanent exile. She did not rebel only against determined identities, she also insisted on the resistance to any artificially constructed poetical demands or designs. For her, one of the most important part of revolution was rebellion against preestablished designs which unruly determine our choices in life. In this context it is interesting to note that Drndic mockingly referred to the contemporary English-language fictional pursuit of "well-rounded characters" 
and "well-told stories", insisting that narratives of exile cannot be orderly or systematic: they simply cannot but be as chaotic and random as the life itself, but this fragmentation of form has to be universal in the modern world which dutifully resists all attempts at interpretation. That the life is unpredictable and therefore fragmented, Drndić understood herself when, at the beginning of the turbulent nineties, she packed her Belgrade life all by herself and headed to Istria the roundabout way, across Hungary, accompanied by her teenage adopted daughter Maša, who followed her later to Canada. Her intention was to join her father in Istria and live with him, but she did not stay in Croatia for long. Drndić's disappointing emigration period spent in Canada between 1995 and 1997 resulted in the semiautobiographical novel Maria Częstohowska still shedding tears or Dying in Toronto (1997) which requires multitudinous rereadings in order to be placed in literary and cultural contexts.

Drndić's first novel Seize the Saturday (Put do subote, 1982) was published in Belgrade, in the then Socialist Federal Republic of Yugoslavia. Her juvenile fiction is rambling and nonlinear, a minimalist and concise novel narrated by a young Belgrade painter of Croatian origin who dutifully follows her husband to Switzerland but returns home without him and starts dating again, without much fulfilment or pleasure. The book is for the most part filled with poignant irony and strangely focused on the heroine's chaotic love life, which is at odds with Drndić of later years, whose idiom remains both bitter and poetic, but becomes filled with anger and melancholy about the unpunished atrocities and unendurable agony of history and politics. The first novel was obviously written in an enthusiastic, hope-filled society of promising perspectives and crumbling socialist idols, whereas Drndić's post-2000 novels deal with apocalypse, recording wars, death and post-Communist resentment at the world that became hectic and irregular.

Drndić is best known for her award-winning, landmark novel Sonnenschein (2007) which has been translated into German, English and Italian, and met with warm critical acclaim. Released in English translation under the title Trieste, the novel traces the port's history from the end of Habsburg rule through fascism in the 1920s to Nazi occupation and the establishment of the San Sabba concentration camp in 1943, although it focuses on the life of a single woman who spends six decades of her life waiting for her abducted son to come home. Cities change names from German to Italian and back again, while indigenous languages and identities are humiliated, spurned and suppressed, and that is why we can notice intended linguistic irony in the name of the protagonist Haya Tedeschi - etymologically, her last name is the Italian word denoting someone or something of German origin, although she is a Jew. Symbolically, the name refers to the endless migration of national identities which periodically leads to atrocities and war crimes, or to a systematic and persistent cultural repression. 
Haya Tedeschi is, paradoxically, a fictional character amid historical facts and she becomes the readers' informed guide through real events and historiographic discourse. Tedeschi is a name Haya's son Franz, who was originally named Antonio, never knew: the boy born out of wedlock was abducted and put up for adoption through the Lebensborn program, which enabled orphans to become a part of an Aryan family. Sonnenschein opens with a first reunion between Haya and Franz when he is aged 62, and although it focuses on Haya's biography, it also incorporates 42 pages naming the 9,000 Jews deported to or murdered by Italy during the Second World War, thus mirroring Haya's personal loss in the multitude of human tragedy.

According to James Young, the problem with such "docu-novels," about the Holocaust such as Drndić's Sonnenschein is "that by mixing actual events with completely fictional characters, a writer simultaneously relives himself of an obligation to historical accuracy (invoking poetic license), even as he imbues his fiction with the historical authority of real events" (Young 76-77). An obsessive return to events from the past that are both traumatic for individuals and for whole societies is characteristic of Drndić's reflections (we see, and understand, that she is primarily interested in the World War II period), and there are, according to some critics, at least two underlying reasons for this. The first is the conviction that people today are obliged to remember all those unknown, neglected, half-forgotten and "weak" victims with an acute sense of responsibility, and this is also the reason why Drndić consistently places the importance of microhistory over that of great historical syntheses. The second reason for her repeated return to dramatic events from the period of World War II rises from the conviction that the present time can never function in a vacuum and that reality consists of parallel histories that create a wide network of connections and mutual influences between past and present. By asking indirectly how to save those who are already gone, Drndić writes her book in order to suggest that this can be achieved only by restoring the memory of a specific, singular person, of someone who has a name, surname, and a unique story, thus bringing them out of the unidentified multitude of humanity. People are forgotten only when their names are forgotten, we are told by the narrator of Drndić's subsequent novel Belladonna, who recalls a saying by Gunter Demnig: "For every name carries a story and history predominantly remembers the names of criminals, forgetting the names of the victims." Through her texts, Drndić persistently opposes the reduction of a person (whether dead or alive) to a number because "murder became possible when an individual turned into a number, when people's uniqueness was taken from them."

The works of Drndić often have a mosaic-like, rich and entangled polyphonic structure with some fragments even coming close to essayist discourse and moralist contemplation, making it possible for the author to mix temporal per- 
spectives in order to connect reflections on the past with a contemporary point of view and to include fragments of autobiographical narration interspersed with metatextual inclusions. The fragmentary character of this prose is evident both on the level of the whole text and on the level of structure, composition and unity. Drndić relies on "the aesthetic of radical montage to absorb, recycle, and re-mediate ready-made commemorative forms" related both to the Holocaust and the ethnic conflicts in former Yugoslavia into fictional narratives. Daša Drndić insisted that she uses "fiction and faction - transcripts, photographs, documents" and that she twists them: "I enjoy myself, twisting these realities." Drndić applies memorabilia and monuments, lists of names, photographs, court transcripts, and witness accounts into her fictional text, hoping to reach the lost integrity of life, death and memory. Whereas with Albahari displacement becomes the meeting point of experimental minimalism and postmodernist surrealism, Drndić indulges in numerous parallel stories, consecutive texts, disturbing testimonies and personal histories.

The "anti-historicist" aspects of Drndić's novels can be spotted in the way they establish crude and intense parallels and correspondences between fascist and nationalist populace, as well as the mass atrocities committed in the name of those ideologies. Using a fictional character as a guide through historical turmoil, Drndić renounces the detailed plot in favour of historiographical discourse, determined to construct collective memory which crosses ethnic and national boundaries, and unites accidental partners in their struggle against oppression.

Dying in Toronto, which chronicles the odd jobs, unemployment, food banks, secondhand clothes, brutal summer and winter temperatures, brings together diverse memories, notes and documents that testify to intellectual crisis, feelings of isolation and defeat as well as to a terrible humiliation lurking behind the apparent security and comfort offered to a displaced person. After two years spent in Canada, the narrator and her daughter return to Croatia, where the war has finished. Daša Drndić narrates about her Canadian migrant experience as a never-ending series of mounting losses: her character, at the same time her doppelganger, a secret sharer and her mighty opposite, feels that she is losing her country, memory, language, art and identity. Displacement is too painful a condition to be simply shrugged off as a temporary crisis or a fleeting state of mind, but the author simply refuses to rescue herself by leaving the turbulent history of her lost homeland behind: she prefers to return to it with a renewed potential of both self-examination and suffering.

\section{Conclusion}


Post-Yugoslav writers look for facts and figures which can be reflected in fictional discourse devised neither to entertain nor to instruct. The powerful and absorbing novels by Daša Drndić are written with the noble intention to reenact eternal human quest for wisdom and peace. She and her fictional doppelgangers boldly ask questions, share experiences, and tell stories, in order to challenge oppression.

The hard facts of the past cannot be altered in any way, as the past already happened, the damage has been done and the consequences are here to stay for a longer period of time. There is no way to resurrect the dead through art, literature or an act of remembering, but there is still hope of empathy and recognition. Daša Drndić was never optimistic about the possibility of restoration of the past, and we might say that her novels are written in the mood of a brooding melancholic and resentment at the same time. Her writing is not trying to bring back what is lost, but it inaugurates radically uncertain and delicate perspectives for future.

\section{WORKS CITED}

Drndić, Daša. Sonnenschein. Zaprešić: Fraktura, 2007.

Drndić, Daša. April u Berlinu. Zaprešić: Fraktura, 2009.

Kellaway, Kate. Children's picture book artists tell migrants' stories through postcards. The Observer, $4^{\text {th }}$ May 2019. https://www.theguardian.com/ artanddesign/2019/may/04/childrens-picture-book-artists-tell-migrantsstories-through-postcards. Accessed May 5 $5^{\text {th }} 2019$.

Postnikov, Boris. Između fikcije i svjedočanstva: Kiš, Albahari, Drndić. Kultura, 156 (2017): 48-61.

Seyhan, Azade. Writing Outside the Nation. Princeton, N. J.: Princeton University Press, 2001.

Young, James E. Writing and Rewriting the Holocaust: Narrative and the Consequences of Interpretation. "Holocaust Documentary Fiction: Novelist as Eyewitness”. Bloomington and Indianapolis: Indiana University Press, 1988. 